\title{
A TALE OF TWO ROYAL CITIES The Narratives of Islamists' Intolerance in Yogyakarta and Solo ${ }^{1}$
}

\author{
Muhammad Najib Azca; Hakimul Ikhwan; Moh Zaki Arrobi \\ Gadjah Mada University, Yogyakarta, Indonesia \\ email:najibazca@ugm.ac.id
}

\section{Abstract}

The article discusses the narratives of "Islamist" intolerance in two cities of Yogyakarta and Solo in the post-Subarto era. It aims to elucidate the multiplicity of intolerance acts and the complexity of underpinning factors to intolerance. It argues that Islamist intolerance has manifested in various forms, ranging from the ideological, instrumental, and symbolic form. However, these categorizations of ideological, instrumental, and symbolic are not clear-cut and permanent one, but there is always some possible overlap between them. There is also the possibility that the form of intolerance can change in different times and occasions. This study is based on fieldwork research taken during 2014-2016 in both cities. Methodologically, this research-based article used Extended Cased Method (ECM). The data was collected by employing indepth interview and participant observation with secondary sources such as local media and government documents.

Tulisan ini membahas narasi Islam intoleran di dua kota, Solo dan Yogyakarta, pasca rezim Soeharto. Selain itu juga menjelaskan sejumlab aksi intoleran dan kompleksitas faktor-faktoryang berkelindan didalam peristiwa tersebut. Tulisan ini mengajukan argumen bahwa Islam intoleran mempunyai

1 Thanks to Syahrul Hidayat, Rochdi Mohan, Fachri Aidulsyah, and Rizky Alif for their contribution in the process of data collection and discussion. Also, thanks to the Faculty of Social and Political Science of Gadjah Mada University for research grant that enable to conduct this research. 
ragam bentuk, mulai dari ideologis, instrumentalis bingga simbolis. Meskipun demikian, kategori tersebut tidak bersifat kaku dan permanen, tetapi terkadang bersifat saling overlap satu sama lainnya. Ada kemungkinan juga bentuk intoleran berubah seiring dengan perubahan waktu dan kondisi. Kajian ini berdasarkan pada studi lapangan di dua kota pada rentang waktu 2014 - 2016. Secara metodologi kajian ini menggunakan pendekatan Extended Cased Method (ECM). Data dikumpulkan melalui serangkaian wawancara mendalam dan observasi partisipatif dengan didukung data sekunder dari arsip daerah dan sejumlah media surat kabar lokal.]

Keywords: Islamist intolerance, symbolic, instrumental, ideological

\section{A. Introduction}

This paper is based on comparative research in Yogyakarta and Solo with the main focus on the resurgence of Islamist intolerance in both cities. Major existent researches on Islamist intolerance employ actors and networks approach, ${ }^{2}$ or structural explanation related the development of democratization in post Suharto. ${ }^{3}$ Within this frame,

2 M. Najib Azca, "After Jihad: a Biographical Approach to Passionate Politics in Indonesia", Ph.D Dissertation (Amsterdam: Universiteit van Amsterdam, 2011); Greg Barton, Indonesia's Struggle: Jemaah Islamiyah and the Soul of Islam (Sydney: University of New South Wales Press, 2004); Martin Van Bruinessen, "Genealogies of Islamic Radicalism in Post-Suharto Indonesia", South East Asia Research, vol. 10, no. 2 (2002), pp. 117-54; Martin Van Bruinessen, Contemporary Developments in Indonesian Islam: Explaining the "Conservative Turn" (Singapore: Institute of Southeast Asian Studies, 2013); Greg Fealy and Sally White (eds.), Expressing Islam: Religious Life and Politics in Indonesia (Singapore: Institute of Southeast Asian Studies (ISEAS), 2008); Vedi R. Hadiz, "Towards a Sociological Understanding of Islamic Radicalism in Indonesia", Journal of Contemporary Asia, vol. 38, no. 4 (2008), pp. 638-47; Noorhaidi Hasan, Laskar Jihad: Islam, Militancy, and the Quest for Identity in Post-New Order Indonesia (Ithaca N.Y.: Southeast Asia Program Publications, Southeast Asia Program, Cornell University, 2006); Haedar Nashir, Gerakan Islam Syariat: Reproduksi Salafyah Ideologis di Indonesia (Jakarta: PSAP, 2007); John Thayer Sidel, Riots, Pogroms, Jihad Religious Violence in Indonesia (Ithaca: Cornell University Press, 2006).

3 Arskal Salim, Challenging the Secular State the Islamization of Law in Modern Indonesia (Honolulu: University of Hawaii Press, 2008); Gerry van Klinken, Communal Violence and Democratization in Indonesia: Small Town Wars (New York: Routledge, 2007); Luthfi Assyaukanie, Islam and the Secular State in Indonesia (Singapore: Institute of Southeast Asian Studies, 2009); Greg Barton, "Islamic Liberalism and the Prospect for Democracy 
intolerance acts frequently viewed as either a matter of political identity or a manifestation of contested social (and political) sphere in democratizing Indonesia post-Suharto.

Choosing a different approach, this paper attempts to elucidate multiplicity of intolerance acts as well as the complexity of underpinning factors to intolerance. It starts by discussing the different trajectory of the political and historical process in Yogyakarta and Solo that has resulted in different forms of public expression as well as the degree of tension regarding Islamist intolerance. This article argues that intolerance manifested in various forms and driven by a variety of force ranging from ideological, instrumental, and symbolic factors. It should be noted that these categorizations of symbolic, instrumental, and ideological are not clear-cut and permanent one but there are some possible overlaps between one and another and may shift over different times and occasions. The link and the interlink between three different kinds of intolerance in both cities will be discussed in the latter part of the paper followed by the conclusion.

Methodologically, this research employs the extended case method (ECM) of Burawoy. ${ }^{4}$ It emphasizes reflexivity that raises the possibility of dialogue and the premise of inter-subjectivity between participant(s) and observer(s). ${ }^{5}$ It also enables a particular case to be extended beyond the locality, region, and even nation to the globe through reconstructing in Indonesia", in Democracy in Asia, ed. by Michele Schmiegelow (New York: Palgrave Macmillan, 1997), pp. 427-53; Yon Machmudi, Islamising Indonesia: The Rise of Jemaah Tarbiyah and the Prosperous Justice Party (PKS) (Canberra: ANU E Press, 2008); Masdar Hilmy, Islamism and Democracy in Indonesia: Piety and Pragmatism (Singapore: Institute of Southeast Asian Studies, 2010); Bernhard Platzdasch, Islamism in Indonesia: Politics in the Emerging Democracy (Singapore: Institute of Southeast Asian Studies, 2009); Saiful Mujani, Muslim Demokrat: Islam, Budaya Demokrasi, dan Partisipasi Politik di Indonesia Pasca Orde Baru (Jakarta: Gramedia Pustaka Utama, 2007); Ariel Heryanto, State Terrorism and Political Identity in Indonesia: Fatally Belonging (New York: Routledge, 2006); Hakimul Ikhwan, "Democratic Islamism: Islamists Engagement with Democratic Politics in Post Suharto Indonesia", Ph.D Dissertation (Colchester: University of Essex, 2015).

${ }^{4}$ Stephen Gilbert Brown and Sidney I. Dobrin (eds.), Ethnography Unbound: Power and Resistance in the Modern Metropolis (Berkeley: University of California Press, 1991); Michael Burawoy, The Extended Case Method: Four Countries, Four Decades, Four Great Transformations, and One Theoretical Tradition (Berkeley: University of California Press, 2009).

5 Michael Burawoy, The Extended Case Method. 
pre-existing theory and engaging theory with data and theory with other theories. Meanwhile, the data collection technique combines in-depth interview and participant observation with secondary sources such as local media and government documents. In-depth interviews were conducted with the diverse social groups in both cities, ranging from Islamist organizations, Non-Governmental Organizations (NGOs) which concern on pluralism and tolerance, and influential local figures. The total numbers of successful in-depth interviews and participant observations were twelve and thirteen respectively.

The article will begin with a brief overview of Yogyakarta and Solo. Then, it will elaborate three different kinds of intolerance actions and their link to the difference of predominant hegemonic power in the respective cities. It follows by a discussion on the link and the interlink of three forms of intolerance in both cities.

\section{B. Twin Kingdoms, Different Fates: A Historical Overview}

This section will provide a brief overview of socio-historical and political trajectory in order to see the link between intolerance actions and power relations that dominated fields of politics, economic, social, and cultural in the two royal cities of Yogyakarta and Solo. It will start by narrating that Yogyakarta and Solo have long historical roots in the history of Islamic Mataram Kingdom as one of the most prominent Islamic-Javanese Kingdom in Nusantara. ${ }^{6}$

The separation of the two Kingdoms occurred after decades of internal war following conflict for the throne between the Prince of Mangkubumi and Pakubuwana III. The conflict forced the two groups into an agreement, which so-called the Giyanti Agreement in 1755. The Agreement finally divided the Mataram into two Kingdoms, namely the Kasunanan of Surakarta under the Pakubuwana III and Kasultanan Ngayogyakarta under the Prince of Mangkubumi, which latter titled Hamengkubuwono I. The Kingdom separation, however, continued in a later period when the Kasunanan had to witness the establishment of a new Kingdom of Mangkunegaran. Meanwhile, the Kasultanan Ngayogyakarta had also broken up by the establishment of

${ }^{6}$ An ancient name for a territory that used to cover major archipelago in the Southeastern Asia 
the Pakualaman led by Prince of Natakusuma, a son of Hamengkubowo I. ${ }^{7}$ The Giyanti Agreement had demonstrated the role of colonial Dutch in the separation of the Kingdom. Indeed, after the Giyanti Agreement, the Dutch was getting stronger and more influential across the Javanese land where the power of Mataram-related Kingdoms was substantially reduced. ${ }^{8}$ In this regard, for the sake of securing political power and economic interest, it was obvious that the Kingdoms tend to become simply local 'collaborators' of the Dutch in favour of colonialization in Java."

Despite relatively similar pathways between the kingdom of Yogyakarta and Solo in the colonial era, the development in postcolonial Indonesia seemed to bring different fates for the two cities. The Kasultanan of Ngayogyakarta took the immediate initiative in the aftermath of Indonesian declaration of independence to support the newly established Republic through the employment of various possible means. The Kasultanan led by a young and smart Sultan Hamengkubuwono IX (HB IX) had clearly stated a notion of support for the Republic in the so-called 'September 5th Mandate Letter', which stated that the Yogyakarta Kingdom is an integral part of Republic of Indonesia. ${ }^{10}$ Moreover, a distinct leadership quality was also shown by the Sultan HB IX when, for the sake of the survival of the new Republic during the early independence, he allowed Yogyakarta to be a temporary capital city for Indonesia since the Capital Jakarta was considered as unsafe. Not only was the Sultan facilitating a shift of the capital but also he provided the Keraton's cash reserves to financing Indonesia's officer salary for four months consecutively. In addition, he was also regarded as a mastermind behind the ' 6 hours military operation' in Yogyakarta demonstrating to the international communities that the

7 Selo Soemardjan, Perubahan Sosial di Yogyakarta (Yogyakarta: Gadjah Mada University Press, 1981).

8 Ibid., p. 23.

9 J.J. van Klaveren, The Dutch Colonial System in the East Indies (Dordrecht: Springer, 1983); Keat Gin Ooi, Southeast Asia: A Historical Encyclopedia from Angkor Wat to East Timor (Santa Barbara: ABC-CLIO, 2004); Anthony Reid (ed.), The Last Stand of Asian Autonomies: Responses to modernity in the diverse states of Southeast Asia and Korea, 1750-1900 (Basingstoke, Hampshire: Macmillan, 1997).

10 Mark Woodward, Java, Indonesia and Islam (New York: Springer, 2010). 
republic remained to exist. ${ }^{11}$ Given all these contributions to the Republic, Yogyakarta has been honoured with a special autonomy where one of the privileges is that the governor is not elected by the people but rather appointed Sultan. This status of special autonomy has been again affirmed by the Law Number 13 the Year 2012 on Special Status of Yogyakarta.

On the other hand, the Kasunanan and Mangkunegaran in Solo had a rather less significant role in the struggle for independence of Indonesia. Instead of fighting against the Dutch and joining with the Republicans, both Kingdoms preferred to maintain collaboration with the Dutch in order to secure political power. This was because both Kingdoms had to deal with contentious local socio-political development due to the severe rivalry between the two in the early 20 th century. In this regard, both Kasunanan and Mangkunegaran formed civilian organizations of Pakempalan Kawoelo Soerokarto (PKS) and Pakempalan Kawoelo Mangkoe Negaran (PKMN) respectively in order to consolidate popular support that supposedly strengthens the legitimacy of the leaders. ${ }^{12}$ Besides, the newly appointed Kings were having a leadership problem. The Pakubuwana XII and Mangkunegaran VIII who led Kasunanan and Mangkunegaran respectively during this turbulent time represented a poor character, lack of leadership, and tend to be in favour of supporting the Dutch. ${ }^{13}$

In addition to the conflict of elites, the weakening Kasunanan and Mangkunegaran in Solo have also related to the anti-swapraja (Special Autonomy) movement organized by popular-based radical groups that challenged the political authority of two kingdoms. The movement demanded to the Republic to vanishing the special status (Swapraja) in Solo through various ways such as mobilizing people gathering, signing the petition, pronouncing declaration, and kidnapping key figures of aristocrats. ${ }^{14}$ The turmoil and chaotic situations in the region had forced the Republic to suspend Kasunanan and Mangkunegaran political power

11 Mohamad Roem et al., Tabta Untuk Rakyat: Celah-Celah Kebidupan Sultan Hamengku Buwono IX (Jakarta: Gramedia, 2011), pp. 76-7.

12 George D. Larson, Masa Menjelang Revolusi: Keraton dan Kebidupan Politik di Surakarta, 1912-1942 (Yogyakarta: Gadjah Mada University Press, 1990), pp. 263-5.

13 Ibid., p. 209; Benedict Anderson, Java in a Time of Revolution: Occupation and Resistance, 1944-1946 (Jakarta: Equinox Publishing, 2006), pp. 347-56.

14 Julianto Ibrahim, Bandit dan Pejuang di Simpang Bengawan: Kriminalitas dan Kekerasan Masa Revolusi di Surakarta (Wonogiri: Bina Citra Pustaka, 2004), pp. 157-64. 
and eventually transformed them into ordinary Karesidenan (region) with the issuance of Presidential Regulation (PP) No 16/SD/1946. ${ }^{15}$ This had substantially signified the bankrupt of political authority of the Kasunanan and Mangkunegaran. Therefore, in the post-independence Indonesia the Kasunanan and Mangkunegaran in the City of Solo did not have a special autonomy status, and indeed the role of the Kingdoms was getting weak in the local politics and policy-making processes in the era of the Republic of Indonesia.

The above discussion has shown that socio-political and historical process led to different predominant-hegemonic power in the two royal cities of Yogyakarta and Solo. In Solo, the Keraton has become less and less powerful, as the Indonesia nation-state developed. The Keraton of Solo (Kasunanan and Kasultanan) has a very limited legitimacy of cultural and political authority. ${ }^{16}$ Conversely, the Keraton of Yogyakarta has remained a key player in the State politics and policy-making since the very early period of independence under the Old Order of Sukarno (19451966) to the New Order of Suharto (1966-1998). In the Reformasi era (post-Suharto), it has received a Special Autonomy status that authorized the Sultan to also serve as a Governor, although there were groups that voiced up to demand democratic election for the Governor.

Consequently, in the post-independence Indonesia, the Keraton of Yogyakarta has been able to embrace large cultural and political authority as a Sultan as well as a Governor. Meanwhile, the Kasunanan of Surakarta and Mangkunegaran have limited authority in the realm of culture and especially politics. Therefore, the special autonomy of Yogyakarta has based on the fact that Yogyakarta has maintained its cultural symbolism of Javanese culture and political roles in defending the nation-State of Indonesia. In the period of revolution, the Sultan was a respectful Republican. In the transitional period of 1965/66, the Sultan had also played a significant role in supporting the New Order of Suharto that subsequently appointed him to serve as a Vice President of Indonesia in 1973-1978. In the period of the massive political reform in the late

15 Ibid., p. 165.

16 G. Ambar Wulan Tulistyowati, "Perubahan Tata Pemerintahan dari Swapraja/ Daerah Istimewa menuju Karesidenan Surakarta Tahun 1945-1950”, Master's Thesis (Jakarta: Universitas Indonesia, 2001). 
1990s, the Sultan HB X joined the crowd of people and activists on the street in order to support the Reform movement. ${ }^{17}$

Furthermore, the hegemonic role in religio-cultural, political and economic field has placed the Keraton in a central position in Yogyakarta's society. Sultan as the embodiment of Keraton power has taken a significant role in any critical situation at the local as well as at the national level. For instance, during the political uncertainty and growing religious tensions after the collapse of New Order in 1998, Sultan Hamengkubuwono $\mathrm{X}$ had been playing crucial role when he persuaded people to avoid anarchism and led enormous peaceful demonstrations in Yogyakarta. ${ }^{18}$ It was widely known that Yogyakarta became one of the most peaceful cities during the political transition period. It also proved that the Sultan of Yogyakarta was able to control its city dwellers from unrest and violence following the collapse of the New Order in 1998. Contrary to this, Solo had experience of urban riot and violence in May 1998, few days before President Soeharto resigned from power. ${ }^{19}$ It reflected the limited social role and lack of cultural legitimacy belongs to the Keraton of Solo both on socio-cultural and political issues. The absence of hegemonic cultural authority in Solo led to 'direct contestation' between secular-nationalist and Islamist forces in several public arenas in the city of Solo as will be discussed in the next section.

\section{Three Forms of Intolerance Act}

The difference of historical and political trajectory has an impact on the forms of contestation between Islamists and secular-nationalist groups in Yogyakarta and Solo. Yogyakarta was prominent as the city of tolerance especially following the Sultanate's influence in preventing mass riots during the political transition in late1990s. However, the story

17 Woodward, Java, Indonesia and Islam.

18 Yustinus Tri Subagya, Support for Ethno-Religious Violence in Indonesia (Yogyakarta: Universitas Sanata Dharma, 2015), p. 45; S.R. Panggabean and B. Smith, "Explaining Anti-Chinese Riots in Late 20th Century Indonesia", World Development, vol. 39, no. 2 (2011), pp. 231-42.

19 Lambang Trijono, "The Political-Economic Crises and Anti-Chinesse Riot: A case of the May 1998 Solo Riot in Indonesia”, Master's Thesis (Sydney: University of Sydney, 2001). 
was reversed recently, at least in the last few years, signified by a sharp increase in intolerance attacks. The Wahid Institute reported that in 2014 and 2015 Yogyakarta ranked the second largest intolerance incidents in Indonesia, just after the West Java Province.

This paper argues that the repeated intolerance acts manifested not in a single form but a rather multiple, either symbolic, instrumental, or ideological. The actions are not always related to a transcendental orientation of 'serving God' or purification of religious meanings and teachings. Rather, multiple underpinning motives brought Islamists to commit intolerance forms of action. Thus, intolerance actions can be symbolic, instrumental, and ideological form. This categorization is not fixed, clear-cut and permanent as there will be a possibility to shift from one form into another over different times and occasions. It should be noted here that there were several occasions in which the Islamists may utilize more than one form of intolerance at the same time in order to pursue their different objective and to winning over different groups.

\section{Symbolic Intolerance}

First of all, the Islamists may take intolerance form of action in order to promote group symbolism that expectedly acts as 'master of the signifier ${ }^{20}$ and thus supposedly will unite or establish a common-bounded sentiment among the group members. In this regard, the symbolism has, in the eyes of Islamists, corresponded to doctrines and teachings, or at the very least the morality, of Islam. The production of the symbolism may have no direct correlation or intention for materialistic gains. It reflected, for instance, in various events organized by the Islamists such as carnival, festivities, and patrols on the streets.

Symbolic intolerance refers to a reproduction of symbolism that attaches to a particular constructed meanings and relates to a particular social context. It can be understood as an attempt to consolidate members of groups as well as internal resources. Within this symbolic movement, the contestation was not only related to economics and politics but also

${ }^{20}$ Chantal Mouffe, The Return of the Political (London: Verso, 1993); Chantal Mouffe, "Deliberative Democracy or Agonistic Pluralism?", Social Research, vol. 66, no. 3 (1999), pp. 745-58; Ernesto Laclau and Chantal Mouffe, Hegemony and Socialist Strategy: Towards a Radical Democratic Politics, trans. by Winston Moore and Paul Cammack (London: Verso, 1985). 
related to meanings, symbols, values, and reconstruction over a particular social entity. This form of intolerance frequently mobilizes an identity at both individual and societal intensively.

Based on field observation in Yogyakarta and Solo, the symbolic form of intolerance has manifested in the anti-Shia movement. The Shia community has actually long historical roots in Indonesian society as reflected in the existence of Syiah-associated tradition across the archipelagic Indonesia such as the Tabot Festival in Bengkulu and the tradition of red-rice porridge among the Javanese in a celebration of the 10th Muharram, a special day of ceremonial amongst the Shi'ites ${ }^{21}$. These local traditions have also proved evidence that the coming of Shia to Indonesian archipelago used to accommodate local tradition and culture, although there was a tendency in the last decade that Shia has become more figh (religious law of worship) oriented. Currently, there are two prominent Shia-related organizations in Indonesia, namely the Ikatan Jamaah Ahlul Bait Indonesia (IJABI) and the Ahlul Bait Indonesia (ABI).

In Yogyakarta, the Islamist groups such as the FUI (the Forum of Adherents of Islam), MMI (the Indonesian Mujahedeen Assembly), FKAM (the Communication Forum of Mosque Activists), FJI (the Forum of Jihadists of Islam), and other lascars have been actively campaigning against the Shia and Communism through various means of movements such as public oration, seminar, patrol, and demonstration. For instance, the event of 31 May 2015 in Yogyakarta's northern yard (Alun-alun Utara) was designed for anti-Shia gathering where a number of prominent figures gave a speech to cautious public awareness about the 'threat' of Shia. The main tagline of the event was 'Yogyakarta Without Shia.' However, in the midst of the crowd, the banners of anti-shia have also flooded and used to present along with the banner of 'anti-Communists.' In Solo, the movement of anti-Shia has also attracted massive public attention. Here, the proponents of anti-Shia movements were the Laskar Umat Islam Surakarta (LUIS), FKAM, and the Dewan Syariah Kota Surakarta (DSKS). They were actively organizing a campaign of anti-Shia, including in the Tauhid Parade held on 16 May 2015.

21 Chiara Formichi, "Shaping Shia Identities in Contemporary Indonesia between Local Tradition and Foreign Orthodoxy", Die Welt des Islams, vol. 54, no. 2 (2014), pp. 212-36. 
Despite to the huge masses mobilization in the anti-Shia demonstration, our research found that there were very insignificant numbers of Shia members in Yogyakarta and Solo. Throughout several interviews with actors who involved in the campaign of anti-shia, the movement actually had no clear targetted Shia groups. For instance, in Yogyakarta Shia is very insignificant in terms of members as well as organizations. The most prominent associated-Shia is the Rausyan Fikr, a small group of study and discussion particularly about philosophy and thoughts of Shiah scholars. The organizations of the IJABI (Ikatan Jamaah Ahlul Bait Indonesia) and the ABI (Ahlul Bait Indonesia) were also unrecognized in Yogyakarta. In Solo, the anti-Shia movements have targetted Habib Rizieq, a central figure of the Islamic Defender Front (FPI), and Ustadz Mudzakir, a charismatic scholar and leader of the Pesantren Al-Gumuk with thousands of Santri (Islamic students), as well as Ustadz Khairul, a respectable head of the Solo FPI. The anti-Shia campaign also targeted Jose Rizal, a prominent activist of a humanitarian non-government organization named MERCI.

In addition to that, the symbolic dimension of anti-Shia movement can also be found within the 'raison de etre' of Islamist umbrella organization both in Solo and in Yogyakarta. The story of how the DSKS came into existence is probably the best case for demonstrating anti-Shia dimension already exist long before the formation of this organization. An influential head of DSKS told us how the issue of Shia had been one of the main reasons for the establishment of DSKS. He stated to us:

"DSKS born to address the grievances and issues that cannot be answered by the established Islamic organizations such as MUI (Indonesian Ulama Council), Muhammadiyah as well as Nahdatul Ulama. For example, when the people ask about Shia, LDII, Ahmadiyah, and Others Deviant Sects within Islam, these established organizations (NU, Muhammadiyah, and MUI) cannot provide an answer. It is precisely the role of DSKS in addressing these issues to the Umat." ${ }^{22}$

It should be obvious how the discourse of anti-Shia-then transformed into the movement of anti-Shia - has been 'the genetic' of DSKS since the very beginning. In this regard, Shia is considered as the symbolism of 'deviant sect' that threatened 'pure Islam' along with LDII

22 Sukino, interview (19 Aug 2015). 
and Ahmadiyah. In rather similar case, in Yogyakarta, the discourse of anti-Shia has been one of the main concerns of Forum Umat Islam (FUI), an Islamist umbrella organization. Fuad Andreago, a prominent young figure of the FUI said that "Shia along with LGBT and communism could not be tolerated at all in Yogyakarta."

Based on the above, this research argues that the anti-Shia mobilization in Yogyakarta and Solo is not necessarily rooted in the global narrative of theological-ideological conflict between the Sunni and the Shia. ${ }^{23}$ Rather, it aimed to draw a symbolism as a 'master of signifier' that would strengthen a sense of internal group membership. ${ }^{24}$ It has functioned to reconsolidate the Islamists and differentiate them from the nationalists in both Yogyakarta and Solo.

\section{Instrumental Intolerance}

The intolerance form of actions can also be instrumental in order to gain economic and political advantages amidst contested resources of politics and economy. Here, the Islamists were employing forms of intolerance actions as an instrument to gain political and economic benefits following heightened contestation especially between the Islamist and the nationalist groups in democratizing Indonesia. Various forms of mass mobilization, i.e., parade, demonstration, and violence attacks became an instrument to push political and economic bargain over the rival group. It confirms the argument of collective action that takes shape in the resource mobilization approach of social movement theory. ${ }^{25}$ The resource mobilization has become a substantial element in collective action to gain support from constituencies as well as to strengthen pressure over the rival groups.

This research found a number of cases where Islamists contested and indeed be in conflict with their rival nationalists regarding, for instance, control over parking areas, business and trading, and constituencies. In

23 Nathan Gonzalez, The Sunni-Sbia Conflict: Understanding Sectarian Violence in the Middle East (New York: Nortia Press, 2009).

24 Laclau and Mouffe, Hegemony and Socialist Strategy.

25 John D. McCarthy and Mayer N. Zald, "Resource Mobilization and Social Movements: A Partial Theory", American Journal of Sociology, vol. 82, no. 6 (1977), pp. 1212-41. 
this regard, both the Islamists and the nationalists reproduced narratives and form of actions as an intrument to contest one-another in order to win control over a particular political and economic resource. Intolerance form of the action takes place within a process to secure resources that are crucial for maintaining existence and sustainability of the organization. Indeed, control over the resource is also meaningfully important for the group to maintain bargaining position amidst highly contested local power. The field of politics and economic are the major contested arena between the Islamists and their counterpart of nationalists. In regard to politics, both contesting groups are attempting to push their agenda through both formal structure and non-formal processes.

Yogyakarta and Solo have similarities in certain contested fields. In Solo, the major field of political contestation is related to electoral politics of Head of the District. Here, the nationalists of PDIP (Indonesian Democratic Party of Struggle) almost always won the Executive Head election in post-Reformasi Indonesia. Since the Reformasi to 2014 election, but the 2004 election, the PDIP always got the majority votes both in Legislative and Executive Elections. Thus, the nationalist PDIP has been very dominant and indeed determinant in the local politics of Solo in the post-Suharto era. As has been discussed above, the PDIP has successfully controlled the local executive office with a significant vote, for instance, in 2011 when the PDI-supported candidates of Jokowi and FX Rudi were re-elected for the Local Executive Head with a fantastic vote of 90,09 percent.

Although the Islamist politics has never won the election, it does not mean that they are insignificant in local politics of Solo. It had long historical roots in the pre-independence Indonesia when Solo had become a head-quarter of the Red Sarekat Islam led by Haji Misbah. ${ }^{26}$ This has left a trace to the current profile of Solo Islamists that seem to have strong militancy among its members, although the actual members are quite small. The strong militancy of Islamist groups in Solo has been nurtured by the birth of several radical Islamic boarding schools (pesantren) in Solo areas, such as Pesantren of Ngruki and Pesantren of Gumuk. With their militancy, the political Islamists frequently challenge the domination

26 Takashi Shiraishi, Zaman Bergerak: Radikalisme Rakyat di Jawa 1912-1926 (Jakarta: Pustaka Utama Grafiti, 1997). 
of the nationalist politics of the PDIP. In 2015 election for Executive Head, for instance, the Islamist politics established a coalition consisted of PAN, PKS, and PPP with the secular-developmentalist parties of the Golkar, Demokrat, and Gerindra to support Anung Indri and Fajri as a candidate for the Executive Head. This had proven that the Islamists had successfully established a coalition with other parties in order to challenge the domination of the PDIP, although at the end of the day they still failed to win the election for the Executive Office.

Religious issues have became a mobilizing sentiment employed by the Islamists in order to consolidate internal group members (within the Islamists parties and constituencies) as reflected in the 'Parade Tauhid' that attracted major elements of Islam in Solo such as the NU, Muhammadiyah, Islamic Student Association (HMI), Union of University Student of Muhamadiyah (IMM), KAMMI, MMI, FPI, HTI, Tarbiyah, MTA, LUIS, Laskar Hizbullah Sunan Bonang, FKAM, and DSKS. There were about 100.000 people (as it was claimed by several Islamist media) participated in the Parade Tauhid. ${ }^{27}$ Indeed, as it had mobilized huge masses on the street, the Parade Tauhid had eventually attracted nonIslamist local elite, i.e., the Prince of Wirabumi of the Surakarta Sultanate and the former incumbent Vice Mayor of Solo, Mr. Achmad Purnomo, in order to re-claiming political influence and to winning the heart of Islamic constituencies. The appearance of the Prince Wirabumi and Vice Mayor of Solo might also demonstrate the importance of this event and the recognition of Islamist's militancy and networks. Moreover, broad participation in the Parade Tauhid had also coincided with spreading perception among the Islamists that the running candidate of PDIP, FX Rudi, during his first term service in the Local Executive has been very much in favour of the Christian groups.

Therefore, the emergence of Islamist symbolism like one in the Parade Tauhid can be seen as a form of the instrumentation of Islamrelated symbolism in order to maintain supports and loyalty amongst the constituents for the sake of winning a local election. In addition,

${ }^{27}$ See for example the news in Panjimas.org telling and presenting the pictures of the Tauhid Parade participated by more than a hundred thousand muslims as published at "Galeri Foto Ratusan Ribu Umat Islam Banjiri Parade Tauhid di Solo", Panjimas (18 May 2015), https://www.panjimas.com/galeri/photos/2015/05/18/galeri-fotoratusan-ribu-umat-islam-banjiri-parade-tauhid-di-solo/, accessed 5 Oct 2016. 
intolerance acts can also be a manifestation of economic contestation over controlling parking areas, for instance, between the 'Green militia' and the 'Red militia' associated to the Islamist Party of the PPP and the nationalist PDIP respectively. The rivalry between these two groups has a very long rooted in Yogyakarta. It is almost always related to a conflict over controlling a territory of business. Besides, as they are affiliated to different political parties, the two groups are frequently involved in conflict and violence during the campaign of a political election. The Forum Umat Islam (FUI), has aware that economic resources are very substantial for the sustenance of their organization. Therefore, through their affiliated organizations such as the Gerakan Pemuda Kabah (GPK) and Muslim Green Zone, they keep maintaining control over parking business, security service, and tourism transportation service situated in the heart of Yogyakarta. Several members of GPK in Yogyakarta have also played a role as 'debt collector'. ${ }^{28}$ In Solo, a lot of parking areas in the main roads are controlled by the nationalist thugs affiliated to PDIP, and the most serious challenger for PDIP's domination over parking areas comes from the Islamist militias as stated by Sukino, a Vice Chairman of DSKS. Several clash and incidents between the nationalist thugs and Islamist-militias that have occurred in Solo's recently demonstrate how the nationalist and the Islamist have been fighting each other in order to secure lucrative economic resource from parking areas and security provision.

\section{Ideological Intolerance}

Last but not least, ideology has also driven intolerance expression in public in Yogyakarta and Solo. It refers to a form of actions rooted in ideological contestation between contesting social groups. Here Islamism is defined as an ideology since it is a system of ideas about how the world works with ethical, moral, and normative principles that guide personal and collective action. ${ }^{29}$ The ideological contestation often embodied in

28 Diatyka Widya, "Tradisi, Ekonomi-Politik, dan Toleransi”, MASYARAKAT Jurnal Sosiologi, vol. 15, no. 2 (2010), p. 53.

29 Pamela Oliver and Hank Johnston, "What a Good Idea! Ideologies and Frames in Social Movement Research", Mobilization: An International Quarterly, vol. 5, no. 1 (2000), p. 44. 
historical narratives within a society that has provided a short of values reference amongst members of particular groups. Ideology consists of 'truth claim' over particular social and political issues and events, i.e., the 1965 coup de tat and its following massacres. The movement of against communism, for instance, has almost always effectively mobilized Islamist groups to take patrol or violent attack to group considered as proponents, or at least sympathizers, of the PKI as they were considered responsible for the coup de tat and massacres of 1965.

The issue of the threat of communism has almost always effectively mobilized Islamist groups, with commonly got supports from the army groups, to go to the street and fight against any forms of symbolicassociated to communism or groups that considered as proponents of the ideology of Communism. Tension over communism narrative has rooted in Indonesian history especially back to the coup de tat of 1965. Since then, Communism and Communists - associated to the PKI members-have become an 'enemy of the State' reflected in overwhelmed State's campaigned to against Communism during the New Order regime (1966-1998). ${ }^{30}$ In short, the anti-communism has strongly associated to the agenda of State regime to reproduce State ideology of Pancasila at the national level and the political and economic interest during the Cold War at the global. ${ }^{31}$

The collapse of New Order regime in 1998, however, had an insignificant impact on weakening ideologization of anti-communism, especially amongst the Islamists and the army. Nowadays, communism remains considered as a threat to both the ideology of the Stateamong them the army — and the ideology of theism—among them, the Islamists. In this regard, during 2013 alone, there were numbers of violent attacks under the anti-communism narrative in Yogyakarta such as forced expulsion by the Front Anti Komunis Indonesia (FAKI) over the meeting of ex-political prisoners associated to the 1965 revolt held in the Shanti Dharma, Sleman, Yogyakarta. FAKI is an alliance of various

30 Wijaya Herlambang, Kekerasan Budaya Pasca 1965: Bagaimana Orde Baru Melegitimasi Anti-Komunisme melalui Sastra dan Film (Serpong: Marjin Kiri, 2013).

31 Vedi R. Hadiz, "The Left and Indonesia's 1960s: The Politics of Remembering and Forgetting", Inter-Asia Cultural Studies, vol. 7, no. 4 (2006), pp. 554-69; Ariel Heryanto, State Terrorism and Political Identity in Indonesia: Fatally Belonging (London: Routledge, 2005). 
organizations that having similar orientation and agenda to fighting against communism in Yogyakarta.

The heightened tensions were related to the screening of the 2014 film of the Look of Silence by Joshua Oppenheimer that eventually led to a number of intolerance acts and violence. In Yogyakarta, the screening of the film in Gadjah Mada University and the Indonesian Institute of Art (ISI) was forced to cancel by Islamist vigilantes of the FUI. The FUI militia has also intimidated the screening of it in the State University of Islam. Besides, the FUI militia had also forced the Social Movement Institue, a local NGO, to stop screening the International People's Tribunal (IPT) about Human Right violation in 1965 incident held in Den Haag Netherland.

Meanwhile, the winning of FX Rudi in the 2015 election of the City Mayor of Solo has also been perceived by the Islamists as a symptom of Communism awakening as stated by Zainal, chairman of MUI in Solo in an interview on 23 Sept 2015. As discussed above, the contentious relationship between the Islamists and the Communists has had long roots in Solo, i.e., the fantastic victory of PKI in 1955 election $^{32}$ and the stronghold of nationalist parties before the fusion policy of 1977. In the view of the Islamists, the proponents of the PKI had swung to the PDI following the fusion policy and later to PDIP in the Reformasi era. With this in mind, the reproduction of 'anti-communism' has gained local relevance and indeed resonance in Solo as it has a linkage to local contestation between the minority but militant Islamists and the predominant nationalists of the PDIP. In this regard, Communism has been perceived as a threat, not only to the national ideology of the State but also to the religiosity of the people.

The above narratives demonstrated the resurgence of social tensions at the local had been underpinned by sharp ideological contestation. The narrative of anti-communism has been rooted in the historical legacy of the mid 20th century political and ideological rivalry in Indonesian. Yet under the democratizing post-Suharto Indonesia, the ideological battle has been revived along with heightened political contestation. The

${ }^{32}$ Herbert Feith, Indonesian Elections of 1955 (Ithaca, NY: Modern Indonesia Project, Southeast Asia Program, Dept. of Far Eastern Studies, Cornell University., 1957). 
Islamist forces believe that the 'New Type of Communism' (Komunis Gaya Baru) has been reviving across the archipelago reflected, among others, in the political victory of PDIP, the massive campaign of the 'leftist' ideology, and attempts of redefining the '1965 tragedy' through the 1965 People Tribunal took place in the Hague, The Netherlands, in November 2015.

\section{The Interlink of the Three Forms of Intolerance}

As previously suggested, the delineation of the three forms of intolerance above should not be understood as a clear-cut and rigid categorization. The following section will discuss and demonstrate how these three forms of intolerance might intertwine each other in Yogyakarta and Solo.

One of the most striking cases of how these three forms of intolerance might overlap with one another is the case of 'Tauhid Parade' in Solo. As discussed earlier, the 'Tauhid Parade' was a form of instrumentalization of Islam-related symbolism to win local political contestation in Solo. Nevertheless, the 'Tauhid Parade' can also be understood as 'symbolic intolerance' regarding its capacity to consolidate and unite various Islamic organizations and constituencies in Solo. A hundred of people that attended this parade brought a banner with the length of 2.5 Kilometer written the sentence of Laa Ilaha Illa Allab (No God but Allah) went around the City of Solo. It was an Islamists' response to the "Salib Parade" (the Cross parade) held by Christians three weeks before in the City of Solo that mobilized around 15,000 people with 270 massive wood crusades were shouldered by the youth Christian militias on the streets. ${ }^{33}$ The 'Salib Parade' was organized by the networks of the church in Solo, and more than 1200 participants attended it. In this regard, both 'Tauhid Parade' and 'Salib Parade' were a reflection of symbolism contestation between Islam and Christian forces. Tauhid is the most central tenet and the most important concept of Islam, it is the basis of all Muslim beliefs. While the Christian cross is a representation of the crucifixion of Jesus; it is the best-known of Christian symbolism.

33 See for example the news in Panjimas.org telling and presenting the pictures of the Tauhid Parade participated by more than a hundred thousand muslims as published at "Galeri Foto Ratusan Ribu Umat Islam Banjiri Parade Tauhid di Solo". 
This 'symbolic contestation' was perhaps best reflected in the statement of KH. Wahyudin, the head of Islamic boarding school (Pesantren) of Al Mukmin Ngruki that involved in the 'Parade Tauhid.' He said that 'Muslims in Solo need a supplement after the previous mass mobilization in the Salib Parade. So, we expect Muslims in Solo do not become inferior after the 'Salib Parade' happened. ${ }^{34}$ For the Islamists, it was obvious that the 'Tauhid Parade' was utilized for bolstering the spirit and raising the confidence of Muslims in Solo after the 'Salib Parade' took place. In addition to that, the success story of 'Tauhid Parade' in consolidating Islamic constituencies inspired Islamist networks in other cities to conduct such an event. ${ }^{35}$

Another example is the anti-Shia movement. As discussed earlier, the anti-Shia campaign in both cities should be understood as a symbolic form of intolerance due to its function to consolidate and to unite various Islamist constituencies. However, the anti-Shia mobilization in some cases has related to the contestation over political resources and sphere of influence. For instance, in Yogyakarta, the anti-Shia alliance organized a public discussion of book entitled Mengenal dan Mewaspadai Bahaya Syiah di Indonesia (Recognizing and Caution of the Threat of Shia in Indonesia) followed by the declaration of the Masyarakat Pecinta Sunnah (Sunnah Lover Society) in UGM's mosque in 2013 that was led by the regent of Sleman, Sri Purnomo. This event was organized by Jama'ah Shalahuddin UGM and supported by several Islamist groups. The event should not only be viewed as 'symbolic intolerance' since it brought various Islamist groups to unite, but also it can be seen as 'instrumental intolerance' by Islamists and local elites since the attendance of Sleman's Regent, Sri Purnomo, who attempted to run for the second period of the Executive Head Office in the upcoming regional election in 2015. From this point of view, his attendance and his support for the anti-Shia campaign was an attempt to win the heart of Islamist constituencies to vote for him in the election.

34 See "KH Wahyudin: Saya Dukung Parade Tauhid, Agar Umat Islam Tidak Minder dengan Adanya Parade Salib”, Panjimas (18 May 2015), https:/ /www.panjimas. com/news /2015/05/18/kh-wahyudin-saya-dukung-parade-tauhid-agar-umat-islamtidak-minder-dengan-adanya-parade-salib/, accessed 7 Oct 2016.

35 Sukino, interview (19 Aug 2015). 
In slightly different case, the anti-Shia campaign in Solo was also related to the contestation of the sphere of influence within the Islamist groups themselves. The campaign of anti-Shia that targeted prominent and charismatic ulama in Solo, i.e., Ustadz Muzakir the leader of Pesantren Al-Islam Gumuk can be seen as the contestation within the Islamist themselves. Anti-Shia accusations toward several prominent Islamist figures in Solo have frequently accompanied by the background of personal intrigues, conflict of interest, and the contest for influence among Islamist constituencies. For example, the Chairman of PBB (Star and Crescent Party), an Islamist party, in Solo confirmed that when he was running for a regional legislative seat in the 2014 election, he was attacked and accused by his rivals as a Shia proponent during the campaign period to lowering votes form the constituencies. Thus, in some cases in Solo and Yogyakarta, the anti-Shia campaign should be regarded both as 'symbolic' as well as 'instrumental' form of intolerance.

Anti-Shia campaign in the two cities also reflects the dynamic interplay between global, national, and local dimension within the three forms of intolerance. The changing dynamic of the global, national, and local might lead to the shifting from one to another type of intolerance. Anti-Shia campaign is probably the best case for illustrating it. Anti-Shia campaign has different global, national, and local contexts that shape its expressions and forms of intolerance. Although the division and schism between Shia and Sunni Muslim can be traced into the dispute over Muslim leadership immediately after the Prophet Mohammed's death in the sixth century, it is hard to deny that the rising tide of anti-Shia campaign in the recent time has originated in the geopolitical rivalry between Saudi Arabia and Iran particularly after the Iranian revolution in 1979. It was exacerbated by the recent political dynamics in the Middle East such as Syria and Yemen civil war in which Saudi Arabia and Iran took a different stand among the conflicting parties. Within this struggle for power and influence in the Middle East, the resurgence of anti-Shia campaign and sectarianism sentiment has much to do with the battle for power, resources, and territory. ${ }^{36}$

36 Ian Black, "Sunni v Shia: Why the conflict is more political than religious", The Guardian (5 Apr 2015), https:/ /www.theguardian.com/world/2015/apr/05/sunni-shiawhy-conflict-more-political-than-religious-sectarian-middle-east, accessed 20 Jan 2018. 
Surprisingly, this anti-Shia campaign has been echoed by the Islamists in Indonesia. However, it took different forms of tension shaped by the national and local dynamics. For instance, in Yogyakarta, the Islamists were always promoting that Shia is the 'enemy' for the national integration as well as Indonesian's Muslim ummah as stated by Fuad Andreago, a Commander of Youth Islamist Lascar of Yogyakarta in the interview on 19 June 2015. They were pointing out the political dynamics in the Middle East portraying the expanding role and sphere of influence of Iran. According to them, Indonesia is under threat of Iranled Shia expansion. Thus, they have to defend and to keep Indonesia as 'the Sunni country.' As has been mentioned before, an act of intolerance can be in the form of symbolic intolerance that functioning as solidarity maker to unite various Islamic constituencies. Meanwhile, the anti-Shia campaign has also a political dimension both in Yogyakarta and Solo as reflected in the anti-Shia declaration attended by the Regent of Sleman who was running for the next term and the anti-Shia campaign that targeted prominent Islamist figures in Solo. Accordingly, it was evident that anti-Shia campaign reflects the shifting of intolerance form shaped by the global and national-local dynamics, from a kind of instrumental manoeuvres in the geopolitical rivalry between the Saudi and Iran to the symbolic intolerance among the Islamist at the national and local level in Indonesia.

The narratives above demonstrate that the three forms of intolerance may intertwine each other and there are possibilities that the Islamist can utilize more than one strategy to win over different constituencies and objectives.

\section{E. Concluding Remarks}

The narratives from Yogyakarta and Solo have provided evidence that the structure of power relations has a significant role in the insurgence of Islamist intolerance in both cities. The difference of historical and political trajectory in the two cities shapes difference forms of networks, expressions, and the contentious relationship between the Islamists and the nationalists. The paper argues that Islamist intolerance has multiple and dynamic forms. Islamist intolerance can be manifested in ideological, instrumental, and symbolic forms. It should be stressed 
Muhammad Najib Azca et al.

again that these categorizations are not clear-cut and rigid since these three forms of intolerance might overlap with one another over different events and occasions. They can also shift from one dimension into another following changing dynamic either at local, national, or global level. These three forms of intolerance flourished in the 'contested' and 'limited' socio-political space. They competed for each other in capturing meanings, identities, symbolism, and political-economic resources albeit their expressions and interests were tied and intertwined complexly. As has been discussed throughout this paper, in the courses of dynamics of social and political practices at the local, the contesting Islamists and the nationalists might be engaged in a particular moment of articulation and disengaged in the other. 


\section{BIBLIOGRAPHY}

Anderson, Benedict, Java in a Time of Revolution: Occupation and Resistance, 1944-1946, Jakarta: Equinox Publishing, 2006.

Assyaukanie, Luthfi, Islam and the Secular State in Indonesia, Singapore: Institute of Southeast Asian Studies, 2009.

Azca, M. Najib, "After Jihad: a Biographical Approach to Passionate Politics in Indonesia”, Ph.D Dissertation, Amsterdam: Universiteit van Amsterdam, 2011.

Barton, Greg, "Islamic Liberalism and the Prospect for Democracy in Indonesia", in Democracy in Asia, ed. by Michele Schmiegelow, New York: Palgrave Macmillan, 1997, pp. 427-53.

----, Indonesia's Struggle: Jemaah Islamiyah and the Soul of Islam, Sydney: University of New South Wales Press, 2004.

Black, Ian, "Sunni v Shia: Why the conflict is more political than religious", The Guardian, 5 Apr 2015, https:/ /www.theguardian.com/ world/2015/apr/05/sunni-shia-why-conflict-more-political-thanreligious-sectarian-middle-east, accessed 20 Jan 2018.

Brown, Stephen Gilbert and Sidney I. Dobrin (eds.), Ethnography Unbound: Power and Resistance in the Modern Metropolis, Berkeley: University of California Press, 1991.

Bruinessen, Martin Van, "Genealogies of Islamic Radicalism in PostSuharto Indonesia", South East Asia Research, vol. 10, no. 2, 2002, pp. 117-54.

----, Contemporary Developments in Indonesian Islam: Explaining the "Conservative Turn”, Singapore: Institute of Southeast Asian Studies, 2013.

Burawoy, Michael, The Extended Case Method: Four Countries, Four Decades, Four Great Transformations, and One Theoretical Tradition, Berkeley: University of California Press, 2009.

----, The Extended Case Method: Four Countries, Four Decades, Four Great Transformations, and One Theoretical Tradition, Berkeley: University of California Press, 2009.

Fealy, Greg and Sally White (eds.), Expressing Islam: Religious Life and Politics in Indonesia, Singapore: Institute of Southeast Asian Studies 
Muhammad Najib Azca et al.

(ISEAS), 2008.

Feith, Herbert, Indonesian Elections of 1955, Ithaca, NY: Modern Indonesia Project, Southeast Asia Program, Cornell University., 1957.

Formichi, Chiara, "Shaping Shia Identities in Contemporary Indonesia between Local Tradition and Foreign Orthodoxy", Die Welt des Islams, vol. 54, no. 2, 2014, pp. 212-36 [http://dx.doi. org/10.1163/15700607-00542p04].

"Galeri Foto Ratusan Ribu Umat Islam Banjiri Parade Tauhid di Solo", Panjimas, 18 May 2015, https://www.panjimas.com/galeri/ photos/2015/05/18/galeri-foto-ratusan-ribu-umat-islam-banjiriparade-tauhid-di-solo/, accessed 5 Oct 2016.

Gonzalez, Nathan, The Sunni-Shia Conflict: Understanding Sectarian Violence in the Middle East, New York: Nortia Press, 2009.

Hadiz, Vedi R., “The Left and Indonesia's 1960s: The Politics of Remembering and Forgetting", Inter-Asia Cultural Studies, vol. 7, no. 4, 2006, pp. 554-69 [http://dx.doi.org/10.1080/14649370600982883].

----, "Towards a Sociological Understanding of Islamic Radicalism in Indonesia", Journal of Contemporary Asia, vol. 38, no. 4, 2008, pp. 638-47 [http://dx.doi.org/10.1080/00472330802311795].

Hasan, Noorhaidi, Laskar Jihad: Islam, Militancy, and the Quest for Identity in Post-New Order Indonesia, Ithaca N.Y.: Southeast Asia Program Publications, Southeast Asia Program, Cornell University, 2006.

Herlambang, Wijaya, Kekerasan Budaya Pasca 1965: Bagaimana Orde Baru Melegitimasi Anti-Komunisme melalui Sastra dan Film, Serpong: Marjin Kiri, 2013.

Heryanto, Ariel, State Terrorism and Political Identity in Indonesia: Fatally Belonging, London: Routledge, 2005.

----, State Terrorism and Political Identity in Indonesia: Fatally Belonging, New York: Routledge, 2006.

Hilmy, Masdar, Islamism and Democracy in Indonesia: Piety and Pragmatism, Singapore: Institute of Southeast Asian Studies, 2010.

Ibrahim, Julianto, Bandit dan Pejuang di Simpang Bengawan: Kriminalitas dan Kekerasan Masa Revolusi di Surakarta, Wonogiri: Bina Citra Pustaka, 2004. 
Ikhwan, Hakimul, "Democratic Islamism: Islamists Engagement with Democratic Politics in Post Suharto Indonesia", Ph.D Dissertation, Cholchester: University of Essex, 2015.

"KH Wahyudin: Saya Dukung Parade Tauhid, Agar Umat Islam Tidak Minder dengan Adanya Parade Salib", Panjimas, 18 May 2015, https://www.panjimas.com/news/2015/05/18/kh-wahyudinsaya-dukung-parade-tauhid-agar-umat-islam-tidak-minder-denganadanya-parade-salib/, accessed 7 Oct 2016.

Klaveren, J.J. van, The Dutch Colonial System in the East Indies, Dordrecht: Springer, 1983.

Klinken, Gerry van, Communal Violence and Democratiation in Indonesia: Small Town Wars, New York: Routledge, 2007.

Laclau, Ernesto and Chantal Mouffe, Hegemony and Socialist Strategy: Towards a Radical Democratic Politics, trans. by Winston Moore and Paul Cammack, London: Verso, 1985.

Larson, George D., Masa Menjelang Revolusi: Keraton dan Kebidupan Politike di Surakarta, 1912-1942, Yogyakarta: Gadjah Mada University Press, 1990.

Machmudi, Yon, Islamising Indonesia: The Rise of Jemaah Tarbiyah and the Prosperous Justice Party (PKS), Canberra: ANU E Press, 2008.

McCarthy, John D. and Mayer N. Zald, "Resource Mobilization and Social Movements: A Partial Theory", American Journal of Sociology, vol. 82, no. 6, 1977, pp. 1212-41.

Mouffe, Chantal, The Return of the Political, London: Verso, 1993.

----, "Deliberative Democracy or Agonistic Pluralism?", Social Research, vol. 66, no. 3, 1999, pp. 745-58.

Mujani, Saiful, Muslim Demokrat: Islam, Budaya Demokrasi, dan Partisipasi Politik di Indonesia Pasca Orde Baru, Jakarta: Gramedia Pustaka Utama, 2007.

Nashir, Haedar, Gerakan Islam Syariat: Reproduksi Salafiyah Ideologis di Indonesia, Jakarta: PSAP, 2007.

Oliver, Pamela and Hank Johnston, "What a Good Idea! Ideologies and Frames in Social Movement Research", Mobilization: An International Quarterly, vol. 5, no. 1, 2000, pp. 37-54 [http://dx.doi.org/10.17813/ 
Muhammad Najib Azca et al.

maiq.5.1.g54k222086346251].

Ooi, Keat Gin, Southeast Asia: A Historical Encyclopedia from Angkor Wat to East Timor, Santa Barbara: ABC-CLIO, 2004.

Panggabean, S.R. and B. Smith, "Explaining Anti-Chinese Riots in Late 20th Century Indonesia", World Development, vol. 39, no. 2, 2011, pp. 231-42.

Platzdasch, Bernhard, Islamism in Indonesia: Politics in the Emerging Democracy, Singapore: Institute of Southeast Asian Studies, 2009.

Reid, Anthony (ed.), The Last Stand of Asian Autonomies: Responses to modernity in the diverse states of Southeast Asia and Korea, 1750-1900, Basingstoke, Hampshire: Macmillan, 1997.

Roem, Mohamad et al., Tabta Untuk Rakyat: Celah-Celah Kehidupan Sultan Hamengku Buwono IX, Jakarta: Gramedia, 2011.

Salim, Arskal, Challenging the Secular State the Islamization of Law in Modern Indonesia, Honolulu: University of Hawaii Press, 2008.

Shiraishi, Takashi, Zaman Bergerak: Radikalisme Rakyat di Jawa 1912-1926, Jakarta: Pustaka Utama Grafiti, 1997.

Sidel, John Thayer, Riots, Pogroms, Jibad Religious Violence in Indonesia, Ithaca: Cornell University Press, 2006.

Soemardjan, Selo, Perubahan Sosial di Yogyakarta, Yogyakarta: Gadjah Mada University Press, 1981.

Tri Subagya, Yustinus, Support for Ethno-Religious Violence in Indonesia, Yogyakarta: Universitas Sanata Dharma, 2015.

Trijono, Lambang, "The Political-Economic Crises and Anti-Chinesse Riot: A case of the May 1998 Solo Riot in Indonesia", Master's Thesis, Sydney: University of Sydney, 2001.

Tulistyowati, G. Ambar Wulan, "Perubahan Tata Pemerintahan dari Swapraja/Daerah Istimewa menuju Karesidenan Surakarta Tahun 1945-1950", Master's Thesis, Jakarta: Universitas Indonesia, 2001. Widya, Diatyka, "Tradisi, Ekonomi-Politik, dan Toleransi", MASYARAKAT Jurnal Sosiologi, vol. 15, no. 2, 2010, pp. 37-60.

Woodward, Mark, Java, Indonesia and Islam, New York: Springer, 2010. 